\title{
XLVI. Note on tinfoil grating as a detector for electric waves
}

\section{T. Mizuno}

To cite this article: T. Mizuno (1895) XLVI. Note on tinfoil grating as a detector for electric waves, Philosophical Magazine Series 5, 40:247, 497-506, DOI: 10.1080/14786449508620799

To link to this article: http://dx.doi.org/10.1080/14786449508620799

曲 Published online: 08 May 2009.

Submit your article to this journal ¿

Џ Article views: 2

Q View related articles ¿ 
one-quarter or three-eighths of an inch, and necessarily, therefore, of greater effective cross-section.

It may also readily be seen by inspection that a needle of finite length rednces the effectiveness of all the small-diameter turns along the axis of the coils, thus showing that the waste axial space in ordinary constructions is not of such serious amount relatively, but on the other hand further supporting the other arguments for the employment of a very short needle.

In the interest of uniformity of convention this opportunity is taken to urge upon those who describe sensitive galvanometers, and especially instrument-makers in cataloguing, that they invariably present the data :

$d=$ deflexion in mm. with scale at 1 metre from galvanometer.

$c=$ current in amperes producing that deflexion.

$g=$ the gal ranometer resistance as connected up when $d$ is observed.

$t=$ the time of single swing of the needle when $\theta$ is measured.

These permit the computation of the several measures of sensitiveness :

$$
\frac{d}{c}, \frac{d}{c \sqrt{ } g}, \frac{d}{c \sqrt{g}} \frac{10^{2}}{t^{2}}
$$

so useful in the comparison of instruments, and so essential to an intelligent selection for specific purposes.

Rogers Laboratory of Physics,

Massachusetts Institute of Technology, Boston, September, 1805.

XLVI. Note on Tinfoil Grating as a Detector for Electric Waves. By T. Muzuno, Rigakushi, Professor of Physics, Daïchi Kötō Gakkō*.

1. UCH interested by Herr E. Aschkinass's experiments 1 described in his paper read before the Physical Society of Berlin, I have been induced to repeat them. How far my results confirm his and how far they differ from them will be seen from this note, in which I also give a few tests of the sensibility of tinfoil grating as a detector of electric

* From a separate impression from the Journal of the College of Science, Imperial University, Tokio, Japan, vol. ix. part 1. Communicated by the Author. 
waves, and an account of some experiments to determine the nature of its action.

2. I prepared my gratings by first coating a flat wooden block with tinfoil and then eutting on it a number of fine parallel slits with a sharp knife (see the annexed figure).

$A$ and $B$ are binding screws which are fixed in the block and. facilitate the connexion of the grating with a Wheatstone bridge.

The particulars of the two gratings chiefly used in my experiments were as follows :-

(1) Rectangular in form, $3 \cdot 5$ centim. by $5 \cdot 1$ centim., total number of lines 97 , and the re-

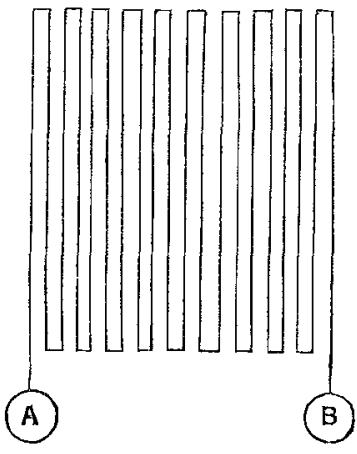
sistance nearly 130 ohms.

(2) Also rectangular, 3.5 centim. by 4.4 centim., the number of lines 118 , and the resistance nearly 232 ohms. 3. My primary vibrator was a brass cylinder 3 centim. in diameter and 26 centim. in length, its surface interrupted midway along its length by a spark-gap, and its ends furnished with brass spheres 4 centin. in diameter forming the poles. The wave-length of the electric waves produced was ascertained to be about 60 centim. The vibrator was placed in the focal line of a wooden parabolic cylinder coated inside with tinfoil, whose height was 76 centim., depth 21 centim., and focal length 12 centim. My resonator is very simple in construction and bas been found very convenient in my other researches on electric waves. It is merely a rectangular strip of tinfoil, 0.8 centim. in breadth and 60 (30 in some cases) centim. in length, with a gap in the middle, which is so fine that resonance-sparks can easily pass across.

4. I will now describe some experiments (Exp. 1 . . Exp. 6) with the view of showing to what extent metallic gratings can screen the action of electric waves.

\section{Experiment 1.}

A wooden board, on which were pasted two parallel tinfoil strips, 33 centim. in length and at a distance of 9.7 centim. from one another, was set up vertically in front of the parabolic cylinder at a distance of about 30 centim. flom the vibrator. The grating No. 1 was brought behind the board, and after exposure for about half a minute to electric waves, its resistance was examined by a Wheatstone bridge. The results obtained were as follows :- 
Detector for Electric Waves.

\begin{tabular}{|c|c|c|c|}
\hline Experiment. & $\begin{array}{c}\text { Initial } \\
\text { Resistance. }\end{array}$ & $\begin{array}{c}\text { Final } \\
\text { Resistance. }\end{array}$ & $\begin{array}{c}\text { Decrease } \\
\text { of Resistance. }\end{array}$ \\
\hline 1. & $129 \cdot 7$ olms. & $123.5 \mathrm{ohms}$. & 6.2 ohms. \\
\hline 2. & 129.7 & $123.4 \quad$ & $6 \cdot 3 \quad$ \\
\hline 3. & $129 \cdot 9$ & $123 \cdot 6$ & $6 \cdot 3$ \\
\hline
\end{tabular}

As Herr Aschkinass mentions, the resistance of the grating once diminished by the action of electric waves could be restored almost to its original value by tapping it. In this experiment, resonance-sparks could be discovered behind the board by means of my tinfoil resonator.

\section{Experiment 2.}

Next, a third strip was pasted on the board, half-way between the other two, and the experiment repeated. The results were:-

\begin{tabular}{|c|c|c|c|}
\hline Experiment. & $\begin{array}{c}\text { Initial } \\
\text { Resistance. }\end{array}$ & $\begin{array}{c}\text { Final } \\
\text { Resistance. }\end{array}$ & $\begin{array}{c}\text { Decrease } \\
\text { of Resistance. }\end{array}$ \\
\hline 1. & 1297 & $123 \cdot 7$ & $6 \cdot 0$ \\
2. & $129 \cdot 8$ & $123 \cdot 8$ & $6 \cdot 0$ \\
3. & $130 \cdot 0$ & $123 \cdot 5$ & 6.5 \\
\hline
\end{tabular}

Here the resonance-sparks behind the board were very feeble.

Experiment 3.

Two more strips were then added bisecting the spaces between those in the experiment 2.

\begin{tabular}{|c|c|c|c|}
\hline Experiment. & $\begin{array}{c}\text { Initial } \\
\text { Resistance. }\end{array}$ & $\begin{array}{c}\text { Final } \\
\text { Resistance. }\end{array}$ & $\begin{array}{c}\text { Decrease } \\
\text { of Resistance. }\end{array}$ \\
\hline 1. & $129 \cdot 8$ & $125 \cdot 8$ & $4 \cdot 0$ \\
2. & $129 \cdot 8$ & $125 \cdot 6$ & $4 \cdot 2$ \\
3. & $130 \cdot 1$ & $125 \cdot 7$ & $4 \cdot 4$ \\
\hline
\end{tabular}

The resonator behind the board gave no sparks in this case. 


\section{Experiment 4.}

Next, a grating, rectangular in form, 27 centim. in length and 22 centim. in breadth, was made, the average distance between two consecutive strips being about $0 \cdot 6$ centim. Placing this grating in a vertical position in front of the parabola and bringing the grating just behind it, the following changes in resistance were observed:-

\begin{tabular}{|c|c|c|c|}
\hline Experiment. & $\begin{array}{c}\text { Initial } \\
\text { Rekistance, }\end{array}$ & $\begin{array}{c}\text { Final } \\
\text { Resistance, }\end{array}$ & $\begin{array}{c}\text { Decrease } \\
\text { of Resistance. }\end{array}$ \\
\hline 1. & $129 \cdot 7$ & $123 \cdot 7$ & 69 \\
2. & $129 \cdot 1$ & $124 \cdot 1$ & $5 \cdot 0$ \\
3. & $129 \cdot 2$ & $123 \cdot 5$ & 57 \\
\hline
\end{tabular}

\section{Experiment 5 .}

Substituting for the above grating a large wire grating, 1.7 metre in the side and with consecutive wires 3 centim. apart, I have found the changes of resistance as follows :-

\begin{tabular}{|c|c|c|c|}
\hline Experiment. & $\begin{array}{c}\text { Initial } \\
\text { Resistance. }\end{array}$ & $\underset{\text { Resistance. }}{\text { Final }}$ & $\begin{array}{c}\text { Decrease } \\
\text { of Resistance. }\end{array}$ \\
\hline 1. & 129.9 & 1265 & $3 \cdot 4$ \\
\hline 2. & $129 \cdot 9$ & $123 \cdot 4$ & $6.5 \perp$ \\
\hline 3. & $129 \cdot 9$ & 1267 & $3 \cdot 2$ \\
\hline 4. & $130 \cdot 2$ & $124 \cdot 5$ & $5 \cdot 7 \perp$ \\
\hline 5. & 1304 & $127 \cdot 0$ & $3 \cdot 4$ \\
\hline 6. & $130 \cdot 3$ & $124 \cdot 1$ & $6.2 \perp$ \\
\hline
\end{tabular}

The signs in the last column of the above table derote the orientations of the wire grating according as the wires were placed parallel or perpendicular to the primary vibrator. The results show how different are the effects of polarized waves on my tinfoil grating. The experiments have shown also how sensitive the tinfoil grating is to the action of electric waves in comparison with my rectilinear tinfoil resonator, because I have found that whereas the former bas shown a 
large amount of change in resistance the latter gave no perceptible resonance-spark.

Experiment 6.

I have now placed my tinfoil grating within a glass belljar which was covered with tinfoil strips. I found that even in this case the change of resistance was distinctly perceptible. Thus :-

\begin{tabular}{|c|c|c|c|}
\hline Experiment. & $\begin{array}{c}\text { Initial } \\
\text { Resistance. }\end{array}$ & $\begin{array}{c}\text { Final } \\
\text { Resistance. }\end{array}$ & $\begin{array}{c}\text { Decrease } \\
\text { of Resistance. }\end{array}$ \\
\hline 1. & $129 \cdot 7$ & $125 \cdot 0$ & $4 \cdot 7$ \\
2. & $129 \cdot 9$ & $125 \cdot 7$ & $4 \cdot 2$ \\
3. & $129 \cdot 9$ & $125 \cdot 6$ & $4 \cdot 3$ \\
\hline
\end{tabular}

This result may be taken to indicate how imperfect would be the protection of an ordinary metallic gauze against powerful electric oscillations.

\section{Experiment 7.}

A circular copper plate 30 centim. in diameter was vertically suspended in front of the vibrator. My tinfoil grating placed behind the plate at a distance of about 12 centim. from it showed the following changes in resistance :-

\begin{tabular}{|c|c|c|c|}
\hline Experiment. & $\begin{array}{c}\text { Initial } \\
\text { Resistance. }\end{array}$ & $\begin{array}{c}\text { Final } \\
\text { Resistance. }\end{array}$ & $\begin{array}{c}\text { Decrease } \\
\text { of Resistance. }\end{array}$ \\
\hline 1. & $129 \cdot 1$ & $121 \cdot 0$ & $8 \cdot 1$ \\
2. & $129 \cdot 3$ & $122 \cdot 3$ & $7 \cdot 0$ \\
3. & 1294 & $122 \cdot 0$ & $7 \cdot 4$ \\
\hline
\end{tabular}

Next, the distance between the plate and the grating was diminished to 2.5 centim. The changes were as follows:-

\begin{tabular}{|c|c|c|c|}
\hline Experiment. & $\begin{array}{c}\text { Initial } \\
\text { Resistance. }\end{array}$ & $\begin{array}{c}\text { Final } \\
\text { Resistance. }\end{array}$ & $\begin{array}{c}\text { Decrease } \\
\text { of Resistance. }\end{array}$ \\
\hline 1. & 1293 & $123 \cdot 0$ & $6 \cdot 3$ \\
2. & $129 \cdot 0$ & $123 \cdot 2$ & $5 \cdot 8$ \\
3. & $129 \cdot 5$ & $123 \cdot 0$ & 6.5 \\
\hline
\end{tabular}


The difference between the results of this and those of the last experiment $I$ am inclined to ascribe to the diffraction effects of electric waves caused by the plate.

\section{Experiment 8.}

A rectangular wooden board, 69 centim. in length and 14 centim. in breadth, was coated all over with tinfoil. When it was held vertically with the longer edges parallel to the primary oscillations, the resistance of my tinfoil grating placed behind it showed no change, but when the edges were placed perpendicular to the primary oscillations, I found :-

\begin{tabular}{|c|c|c|c|}
\hline Experiment. & $\begin{array}{c}\text { Initial } \\
\text { Resistance. }\end{array}$ & $\begin{array}{c}\text { Final } \\
\text { Resistance. }\end{array}$ & $\begin{array}{c}\text { Decrease } \\
\text { of Resistance. }\end{array}$ \\
\hline 1. & $130 \cdot 0$ & $127 \cdot 0$ & $3 \cdot 0$ \\
2. & $130 \cdot 8$ & $127 \cdot 7$ & $3 \cdot 1$ \\
3. & $131 \cdot 4$ & $127 \cdot 8$ & $3 \cdot 6$ \\
\hline
\end{tabular}

This shows that the intensity of the diffraction effect depends on the extension of the tinfoil board with respect to the direction of the primary oscillations.

\section{Experiment 9.}

A parabolic cylinder exactly similar to the one mentioned before was placed against the latter, at a distance of about 1.5 metre, so that their focal lines should be parallel. My tinfoil grating No. 2 was held in the focal line of the second parabolic cylinder and tested; thus :-

\begin{tabular}{|c|c|c|c|}
\hline Experiment. & $\begin{array}{c}\text { Initial } \\
\text { Resistance. }\end{array}$ & $\begin{array}{c}\text { Final } \\
\text { Resistance. }\end{array}$ & $\begin{array}{c}\text { Decrease } \\
\text { of Resistance. }\end{array}$ \\
\hline 1. & $229 \cdot 9$ & $219 \cdot 0$ & $10 \cdot 9$ \\
2. & $229 \cdot 9$ & $219 \cdot 7$ & $10 \cdot 2$ \\
3. & $229 \cdot 9$ & $219 \cdot 6$ & $10 \cdot 3$ \\
\hline
\end{tabular}


Taking away the cylinder, I found :-

\begin{tabular}{|c|c|c|c|}
\hline Experiment. & $\begin{array}{c}\text { Initial } \\
\text { Resistance. }\end{array}$ & $\begin{array}{c}\text { Final } \\
\text { Resistance. }\end{array}$ & $\begin{array}{c}\text { Decrease } \\
\text { of Resistance. }\end{array}$ \\
\hline 1. & 2300 & $227 \cdot 6$ & 24 \\
2. & $230 \cdot 0$ & $228 \cdot 0$ & 20 \\
\hline
\end{tabular}

\section{Eaperiment 10.}

In this experiment, my tinfoil grating No. 2 was placed just in front of a metallic plate, that is to say, near the node of the stationary electric waves produced by the plate, with the following results :-

\begin{tabular}{|c|c|c|c|}
\hline Experiment. & $\begin{array}{c}\text { Initial } \\
\text { Resistance. }\end{array}$ & $\begin{array}{c}\text { Final } \\
\text { Resistance. }\end{array}$ & $\begin{array}{c}\text { Decrease } \\
\text { of Resistance. }\end{array}$ \\
\hline 1. & $222 \cdot 0$ & $200 \cdot 0$ & $22 \cdot 0$ \\
2. & 227.0 & 2060 & $21 \cdot 0$ \\
3. & 228.0 & 206.5 & 21.5 \\
\hline
\end{tabular}

Taking away the plate, I found :-

\begin{tabular}{|c|c|c|c|}
\hline Experiunent. & $\begin{array}{c}\text { Initial } \\
\text { Resistance. }\end{array}$ & $\begin{array}{c}\text { Final } \\
\text { Resistance. }\end{array}$ & $\begin{array}{c}\text { Decrease } \\
\text { of Resistance. }\end{array}$ \\
\hline 1. & $227 \cdot 2$ & $184 \cdot 7$ & 42.5 \\
2. & $225 \cdot 7$ & 184.5 & $41 \cdot 2$ \\
\hline
\end{tabular}

\section{Experiment 11.}

In order to examine whether the orientation of the tinfoil grating with respect to the primary oscillations has an influence or none on the change of its resistance, the following observations were carried out :- 
(1) With the grating No. 1.

\begin{tabular}{|c|c|c|c|}
\hline Experiment. & $\begin{array}{c}\text { Initial } \\
\text { Resistance. }\end{array}$ & $\begin{array}{c}\text { Final } \\
\text { Resistance. }\end{array}$ & $\begin{array}{c}\text { Decrease } \\
\text { of Resistance. }\end{array}$ \\
\hline 1. & $132 \cdot 4$ & $125 \cdot 0$ & $7 \cdot 4 \perp$ \\
\hline 2. & $132 \cdot 2$ & $125 \cdot 5$ & $6 \cdot 7$ \\
\hline 3. & $132 \cdot 4$ & $125 \cdot 2$ & $7 \cdot 2 \perp$ \\
\hline 4. & $132 \cdot 4$ & $126 \cdot 4$ & 60 \\
\hline 5. & $132 \cdot 5$ & 125.5 & $7 \cdot 0 \perp$ \\
\hline 6. & $132 \cdot 7$ & 1265 & 62 \\
\hline
\end{tabular}

(2) With the grating No. 2.

\begin{tabular}{|c|c|c|c|}
\hline Experiment. & $\begin{array}{c}\text { Initial } \\
\text { Resistance. }\end{array}$ & $\begin{array}{c}\text { Final } \\
\text { Resistance. }\end{array}$ & $\begin{array}{c}\text { Decrease } \\
\text { of Resistance. }\end{array}$ \\
\hline 1. & 2320 & 189.9 & $421 \perp$ \\
\hline 2. & $232 \cdot 0$ & $193 \cdot 0$ & $39 \cdot 0$ \\
\hline 3. & $232 \cdot 0$ & $187 \cdot 0$ & $450 \perp$ \\
\hline 4. & $232 \cdot 0$ & $196 \cdot 0$ & 36.0 \\
\hline 5. & $232 \cdot 4$ & $183 \cdot 2$ & $49 \cdot 2 \perp$ \\
\hline 6. & $232 \cdot 2$ & $194 \cdot 5$ & $37 \cdot 7$ \\
\hline
\end{tabular}

The signs in the last column indicate the direction of the tinfoil strips of the gratings with respect to that of the primary oscillations. Thus, the answer may be taken as positive.

\section{Experiment 12.}

Lastly, I performed some experiments to decide the question whether the change of resistance under consideration is a molecular change as in a selenium cell or simply a mechanical one. For this purpose I prepared very carefully another tinfoil grating with a much wider space between the strips. It was rectangular, 7 centim. in length and 6 centim. in breadth, the total number of fine strips being 51 . (See the figure.)

The resistance of the grating thus prepared was 209 olms. 
Now exposing this grating to the action of electric waves, I did not find the least sign of change in its resistance except a very small one due perhaps to the heating effect. The experiment was of course tried several times and also on different occasions, but never with positive result. Here I wish also to notice that although I tried the experiment with fine german-silver wire and also fine iron wire grat-

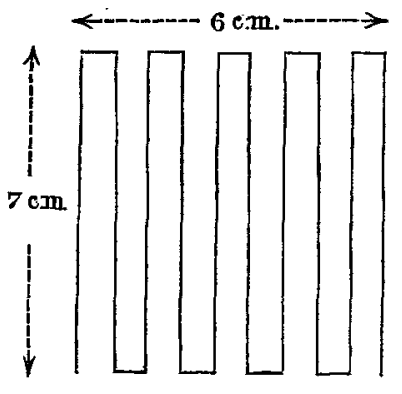
ings, I could never find any decided effect dne to the action of electric waves on them.

\section{Conclusions.}

I. It is certain that the change of resistance of the tinfoil grating is due to the action of electric waves. So far as the electric discharges in the primary spark-gap are oscillatory, they have an effect on the grating, but if not oscillatory, none.

II. Inasmuch as where my rectilinear tinfoil resonator fails the tinfoil grating shows the presence of electric waves, the latter must be regarded as far more efficient than the former as a detector of electric waves. Even a single spark, if oscillatory, is sufficient to produce a large effect on the grating. I would here call attention to the fact that the change in resistance of one and the same grating observed on different days during the course of my research differed in amount. This is certainly due to the conditions of the spark-gap, and consequently the intensity of the primary oscillations, and also somewhat to the time of exposure.

III. The sensibility of gratings may, up to certain limits, be increased by increasing the fineness and closeness of the strips. For, of my two gratings which are nearly equal in their dimensions but greatly different in the number of strips, the first gave the maximum change of about 6 per cent., while the second gave about 19 per cent.

IV. The phenomenon under consideration may not be molecular, and so far as my experiments go, seems to be purely mechanical. Slits ent in tinfoil with a knife, however sharp they may be, surely bave margins which are zigzag. I imagine that the action of electric waves may consist in giving impulses to several strips of tinfoil so as to let the leaflets on 
the margins come in contact with one another and thus cause a diminution of the total resistance of the grating. Especially the fact that the spacing of the strips shonld have so large an influence as to reduce the effect almost to nothing seems to me to favour the above supposition. Also the fact that the change of resistance depends upon the orientation of the strips seems to point in the same direction. Still another fact which is equally important from the above point of view is that the resistance of the tinfoil grating once diminished by an exposure to the action of electric waves can be restored nearly to the original value by tapping the grating. It may be pointed out that Prof. Minchin's experiment ${ }^{*}$ on the action of electromagnetic radiation on films containing metallic powders may stand in close connexion with the present subject.

XLVII. The Development of Artitrary Functions.

By Prof. John Perry and Mr. H. F. Hunt†.

GTUDENTS at the Finsbury Technical College have for $\mathcal{S}$ some years carried out the Fourier development idea of the late Professor Clifford by practical Geometrical methods. The curve which graphically represents the function is supposed to be wrapped round a circular cylinder, and the areas of its projections upon two diametral planes enable the coefficients to be found. In 'The Electrician' of June 28th, 1895, one of us gave detailed instructions for carrying out the process. We do not know of any method of development in a Fourier series which can compare with this in either rapidity or accuracy.

In the discussion of Prof. Henrici's paper, April 13th, 1894, one of us described a graphical method of developing any arbitrary function in a series of other normal forms than sines and cosines, such as Bessels or Zonal Spherical Harmonies. It consisted in wrapping the curve which represents the function round a specially shaped cylinder, not circular, and projecting it upon a certain plane. One of us has wasted many months in finding with great exactness a sufficient number of coordinates of the trace of the cylinder suitable for a Zeroth Bessel development. The labour was unnecessary because the coordinate most troublesome to calculate is not really needed: that is, the actual shape of the cylinder is

* Phil. Mag. [5] xxxvii. p. 90 (1894).

$\dagger$ Communicated by the Physical Society : read October 25, 1895. 